\title{
RECONCILING HUMAN RIGHTS AND THE ENVIRONMENT: A PROPOSAL TO INTEGRATE THE RIGHT TO FOOD WITH SUSTAINABLE DEVELOPMENT IN THE 2030 DEVELOPMENT AGENDA
}

\author{
Ana García Juanatey*
}

\begin{abstract}
This article examines the utility of the human rights-based approach (HRBA) in tackling environmental challenges that face achievement of the right to food in coming decades. So far, such approach has been quite useful in the consideration of equity, discrimination and accountability issues. Nevertheless, the HRBA's utility to tackle the effects of environmental degradation, natural resources depletion and climate change on food security is not that clear, as human rights law and practice has evolved in parallel with environmental concerns until recently. Therefore, this article poses the following question: is the human rights-based approach to food security sufficient to address the environmental problems and constraints that infringe directly on the right to food implementation? And, how can we integrate the needs of future generations in current human rights-based policies and deal with the tradeoffs between present and future needs? This article examines how last years' international legal literature has portrayed the linkages between the environment and human rights, principally in relation to the right to food. Moreover, it also intends to explore possible avenues of convergence, pinpointing opportunities to connect the right to food and sustainable development in the context of the 2030 Agenda. In more concrete terms, it suggests that a greater integration between the right to food and a set of
\end{abstract}

* PhD (Universitat Pompeu Fabra), Visiting Professor at Universitat Pompeu Fabra and Research Fellow at Institut Barcelona d'Estudis Internacionals (IBEI). This article is based on the research conducted at the Food and Agricultural Organization (FAO) between January and March 2015. I thank Juan Carlos García Cebolla and the rest of the Right to Food Team for their warm welcome and help during that period. Part of the views reflected in this article are included too in my PhD thesis entitled, "An Integrated Approach of the Right to Food and Food Security in the Framework of Sustainable Development" (Universitat Pompeu Fabra, 2016), supervised by Professor Ángel J. Rodrigo Hernández. 
principles of sustainable development law may open new avenues for research and advocacy on the right to food.

Keywords: Human Rights, Environment, Right to Food, Human RightsBased Approach, Sustainable Development, Sustainable Development Law

DOI: https://dx.doi.org/10.4314/jsdlp.v9i1.2

\section{INTRODUCTION}

The added value of the right to food ${ }^{1}$ as a tool for fighting hunger has been reaffirmed in the context of the 2030 Development Agenda. In October 2014, two months after the presentation of the SDGs, member states in the 41st session of the Committee on Food Security (CFS) reiterated their commitment to implementing the Voluntary Guidelines for the Progressive Realization of the Right to Adequate Food in the Context of National Food Security (RtFG), ${ }^{2}$ that are intended to incorporate a human rights-based approach (HRBA) to food security policies at national level. Thus, as it was affirmed in International Dimensions of the Right to Adequate Food, the HRBA is invaluable in the 2030 Development Agenda as it helps to move away from the dominant narrow focus on economic growth to an approach that aims to advance equality and non-discrimination and to ensure accountability and coherence in different policy regimes. ${ }^{3}$ Hence, the right to food is a key tool in the hand of states to achieve the SDG-2 target: "end hunger, achieve food security and improved nutrition and promote sustainable agriculture".

1 The expression "right to food" refers to both the "right to adequate food", part of the "right of everyone to an adequate standard of living", and the "fundamental right to be free from hunger", both included in article 11 of the International Covenant on Economic, Social and Cultural Rights.

2 FAO, "Voluntary Guidelines to Support the Progressive Realization of the Right to Adequate Food in the Context of National Food Security" (FAO, 2004) < http: //www.fao.org/docrep/009/y7937e/y7937e00.htm> accessed 10 March 2015.

3 Sisay Yeshanew and Michael Windfuhr, "International dimensions of the right to adequate food" (2014) 7 Right to Food Thematic Study < http://www.fao.org/ righttofood/publications/publications-detail/en/c/271827/> accessed 4 March 2015. 
However, recent research underscored the impact that the current pace of climate change and environmental degradation may have on the implementation of the right to food in the context of the 2030 Development Agenda. As it was emphasized in the outcome document of the last United Nations Conference on Sustainable Development (Rio +20$)$, the loss of biodiversity and the degradation of ecosystems undermine global development, affecting food security and nutrition, the provision of and access to water and the health of the rural poor and of people worldwide, including present and future generations. ${ }^{4}$ In that regard, ground-breaking research has drawn attention to the existing "planetary boundaries", which would be unsafe to transgress for nine Earth-system processes. ${ }^{5}$ Among those, trespassing seven of such boundaries may impact heavily on food systems, especially climate change, biodiversity loss, biogeochemical, ${ }^{6}$ freshwater, land use ${ }^{7}$ and chemical pollution. ${ }^{8}$ In the specific case of anthropogenic climate change, it seems that the ceiling of two degrees that was considered the "point of no return" will very probably be surpassed. ${ }^{9}$ As a result, the consequences for some populations would be massive, especially in vulnerable regions. For instance, a recent report predicted a slower agricultural productivity growth and escalating crises in agriculture in the most resource-constrained and climate-change-exposed regions, which are predominantly in Sub-Saharan Africa and South Asia. ${ }^{10}$ Furthermore, these environmental challenges must be confronted in the context of meagre natural resources and a growing population.

4 UNGA, "The Future We Want" (2012) A/RES/66/288, para $197<$ http:// www.uncsd2012.org/thefuturewewant.html> accessed 4 March 2015.

5 Johan Rockström et al., "Planetary boundaries: exploring the safe operating space for humanity" (2009) 14 (2) Ecology and Society $32<\mathrm{http}: / /$ www.ecologyandsociety.org/vol14/iss2/art32/ > accessed 3 March 2015.

6 This boundary refers to the human alterations in the Earth's nitrogen and phosphorus cycles.

7 The land use boundary pays attention to the conversion of forests, wetlands and other vegetation types into agricultural and other land uses.

8 Chemical pollution includes chemicals, such as persistent organic pollutants, heavy metals and radionuclides, which are present in the environment and have potentially irreversible effects on biological organisms.

9 Working Group II of the IPCC, "Climate Change 2014: Impacts, Adaptation, and Vulnerability" (2014) < https://www.ipcc.ch/pdf/assessment-report/ar5/wg2/ WGIIAR5-FrontMatterA_FINAL.pdf> accessed 3 March 2015.

10 UNCTAD, "Trade and Environmental Review 2013: Wake Up before It Is Too Late" (2013) < http://unctad.org/en/publicationslibrary/ditcted2012d3_ en.pdf $>$ accessed 3 March 2015. 
In this challenging scenario, achievement of the SDGs and effective enjoyment of the right to food are seriously compromised, principally for the people directly depending on the ecosystems. In general, terms, while these implications may affect us all, it is widely recognized that environmental damage is more severely felt by the part of the population already in a vulnerable situation. In fact, many of the regions facing the greatest challenges in achieving the 2015 targets are those facing the greatest problems of ecosystem degradation. ${ }^{11}$ In the case of the human right to food, among the most vulnerable are food producers, which are "inextricably bound up with access to natural resources and issues of environmental degradation and pollution". ${ }^{12}$

Moreover, apart from the impacts of climate change, big development projects such as dam construction or river diversion or the establishment of extractive industries may pollute the ecosystems and deplete the natural resources necessary to produce food. A very graphic example is the case of drying seas and lakes, such as the Aral Sea or Lake Chad. On the one hand, Aral Sea's desiccation and pollution caused by unsustainable agricultural practices led to massive ecological changes that drastically affected the livelihoods of coastal fishing communities, who face insurmountable difficulties to fish or grow safe food. On the other hand, Lake Chad desiccation due to climate change and inefficient damming and irrigation methods prompted a substantial decline in fish production and a reduction of livestock population and biodiversity around the lake. Therefore, the degradation of ecosystems, including natural resources and biodiversity, could translate to a violation of the obligation to respect, protect and fulfil the right to food by destroying resources necessary to produce food. ${ }^{13}$

11 OHCHR and UNEP, "Joint Report on Human Rights and the Environment" (2012) 4 <http://www.unep.org/delc/Portals/119/JointReportOHCHR andUNEPonHumanRightsandtheEnvironment.pdf> accessed 3 March 2015.

12 K. Cook, "The Right to Food and the Environment" (2010) 12 Environmental Law Review 1, 1 <http://vathek.org/doi/pdf/10.1350/enlr.2010.12.1.072> accessed 3 March 2015.

13 This intersection between environmental protection and sustainable use of resources and the right to food is clearly established in Guideline 8 of the Right to Food Guidelines, Democracy and Citizen Participation: Country Case Studies (RtFG). Katharine S. E. Cresswell Riol, Right to Food Guidelines, Democracy and Citizen Participation: Country Case Studies, Routledge Studies in Food, Society and the Environment, Routledge, 10 November 2016. 
This article examines whether, and to what extent, the HRBA would be a valuable tool to tackle environmental challenges that infringe upon the right to food. Thus far, such an approach has proven very useful in tackling equity, discrimination and accountability issues. ${ }^{14}$ Nevertheless, the ability of HRBA to tackle the effects of environmental degradation, natural resource depletion and climate change on food security is not that clear. In relation to that, a crucial question to ask is: how can we integrate the needs of future generations into the current right to food-based policies and how can we deal with the trade-offs between present and future needs? To find answers to this question, this article intends to explore possible avenues of convergence, identifying gaps and opportunities to link the right to food and sustainable development looking at potential synergies for implementation of the 2030 agenda. More concretely, it examines the connections between the right to food and three principles of sustainable development law: the principle of sustainable use of natural resources, the principle of equity and eradication of poverty, and the principle of common but differentiated responsibilities. To do that, this article reviews relevant literature that explores the connections between human rights and the environment.

The article is organized as follows: Section 2 examines the conceptualization and consideration of the HRBA, both in the general work of the UN and at the FAO. Section 3 explores the impact of environmental degradation on the different right-to-food obligations. Section 4 reviews how the connections between the right to food and environmental protection have been addressed in UN discourses and within the scope of relevant literature. In particular, it delves into the constructive dialogue between environmentalists and human rights scholars and activists framed in the corpus of the human rights and environment literature. And finally, Section 5 examines the relationships between the right to food and sustainable development in the context of the 2030 Agenda, paying attention also to the contribution of a set of international law principles of sustainable development, which may complement the current HRBA to food security. Section 6 is the conclusion.

14 CFS, "Right-to-Food Ten-Year Perspective" (FAO, 2014) < http://www.fao.org/ 3/a-ml774e.pdf $>$ accessed 4 March 2015. 


\section{TOWARDS A RIGHT TO FOOD-BASED APPROACH TO FOOD SECURITY}

Since the end of the nineties, the UN has made a considerable effort to mainstream human rights into its development work through the HRBA. According to the UN Statement of Common Understanding on Human Rights-Based Approaches to Development Cooperation and Programming adopted in 2003, the HRBA is aimed at ensuring that any actions intended to advance development do not result in human rights violations. ${ }^{15}$ In practical terms, this entails ensuring that the standards that can be derived from the Universal Declaration of Human Rights and other international human rights instruments effectively guide the work of all UN development programmes as in all sectors and in all phases of the programming process. ${ }^{16}$ To pursue this, the HRBA seeks to mainstream these standards into development planning and decision-making. This set of standards can be summarized into the so-called "PANEL principles": participation, accountability, nondiscrimination and equality, empowerment and legality. ${ }^{17}$ By applying these principles, policy makers are better placed to anticipate and consider the human rights impacts of their policy-making and take steps to prevent and mitigate those impacts.

As part of the UN system, the HRBA has been included also in the work of the FAO, the UN agency responsible for food and agriculture. The FAO Voluntary Guidelines to Support the Progressive Realization of the Right to Food (RtFG) adopted by the 127th Session of the FAO Council in November 2004, are based on this approach. As stated in guideline 7, the RtFG is aimed at providing "practical guidance to States in their implementation of the progressive realization of the right to adequate food in the context of national food security". Since the

15 United Nations Practitioners' Portal on Human Rights Based Approaches to Programming, "The Human Rights-Based Approach to Development Cooperation: Towards a Common Understanding Among UN Agencies" < http:/ /hrbaportal.org/the-human-rights-based-approach-todevelopmentcooperation-towards-a-common-understanding-among-un-agencies $>$ accessed 1 April 2018.

16 Ibid.

17 Scottish Human Rights Commission, "A Human Rights Based Approach: An Introduction", Leaflet <http://www.scottishhumanrights.com/media/1409/ shrc_hrba_leaflet.pdf $>$ accessed 1 April 2018. 
adoption of the RtFG, a right to food-based approach to food security has been developed under the leadership of FAO Right to Food team. ${ }^{18}$ This approach stresses states' obligation to respect, protect and fulfil the right to food, as recognized in the General Comment 12 of the Committee on Economic, Social and Cultural Rights (CESCR). ${ }^{19}$ This right to food-based perspective requires that all phases of decisionmaking comply with seven central "PANTHER principles": participation, accountability, non-discrimination, transparency, human dignity, empowerment and rule of law. ${ }^{20}$ Based on these principles, this right to food-based approach has been positively assessed as it "complements food security considerations with dignity, rights acknowledgment, and transparency, accountability, and empowerment concerns". ${ }^{21}$

One decade after its adoption, FAO member states recognized the significant contribution of the RtFG in guiding national governments in the design and implementation of food security and nutrition policies in the previous ten years. ${ }^{22}$ Therefore, in the context of the approval of the 2030 Agenda for Sustainable Development, the right to food has been recognized as a key tool in the hand of states to achieve the SDG2 target, namely, to "end hunger, achieve food security and improved nutrition and promote sustainable agriculture".

\section{THE IMPACT OF ENVIRONMENTAL DEGRADATION ON THE RIGHT TO FOOD}

Environmental degradation, including problems such as climate change and natural resource depletion, is a major challenge to the achievement of SDG 2: it interferes in different ways with states' obligation to respect,

18 FAO, "The Right to Food" < http://www.fao.org/right-to-food/background/ en/> accessed 1 April 2018.

19 CESCR, "General Comment 12, The Right to Adequate Food" (1999) E/C. 12/ 1999/5, paras 14 to 20 <http://www.fao.org/fileadmin/templates / righttofood/documents/RTF_publications/EN/General_Comment_12_ EN.pdf $>$ accessed 3 March 2015.

20 FAO, "Human Right Principles: PANTHER" < www.fao.org/righttofood/aboutright-to-food/human-right-principles-panther/en/> accessed 19 June 2018.

21 Kerstin Mechlem, "Food Security and the Right to Food in the Discourse of the United Nations" (2004) 10 (5) European Law Journal 631, pp. 631-648.

22 Committtee on World Food Security, "Right-to-Food Ten-Year Perspective" (2014) <http://www.fao.org/3/a-ml774e.pdf> last accessed 4 March 2015. 
protect and fulfil the right to food. ${ }^{23}$ First, according to General Comment 12, states should refrain from taking direct action that negatively interferes with people's enjoyment of the right to food. In relation to that, concern has been raised in regard to the construction of big development projects, such as dam building, which normally entails the expropriation of land, frequently without the payment appropriate compensation, and the damaging of natural resources and ecosystems.

Second, states should also protect people's right to food from the negative environmental externalities of business activity. Accordingly, environmental concerns have been raised regarding all business sectors, including heavy manufacturing, agribusiness, pharmaceutical and chemical companies, retail, and consumer products. ${ }^{24}$ In the case of oil and gas extraction, one of the cases which received more scholarly attention was the environmental damage caused by oil spills and its impact on food production, as recorded among the Ogoni people in Nigeria. ${ }^{25}$

Third, states should also address the harmful impacts of climate change on food production. According to the High-Level Panel of Experts on Food Security and Nutrition (HLPE) and the one on Food Security and Climate Change, the livelihoods of those already vulnerable to food insecurity will be further harmed by climate change. ${ }^{26}$ For that

23 CESCR, General Comment 12, (n 19).

24 John H. Knox. "Report of the Independent Expert on the Issue of Human Rights Obligations Relating to the Enjoyment of a Safe, Clean, Healthy and Sustainable Environment: Mission to Costa Rica" (2014) A/HRC/25/53 Add 1.

25 After the spills from 1976 to 1991, crops and trees were destroyed. However, compensation was modest and took no account of longer-term impacts. Richard Boele, Heike Fabig, David Wheeler, "Shell, Nigeria and the Ogoni. A Study in Unsustainable Development: II. Corporate Social Responsibility and "Stakeholder Management" Versus a Rights Based Approach To Sustainable Development" (2001), 9 Sustainable Development 121, pp. 121-135. Moreover, new spills took place in the Bodo area of the Ogoniland in 2008, affecting settlements that depended on the area for food and water. Alicia Fentiman and Zabbey Nenibarini, "Environmental Degradation and Cultural Erosion in Ogoniland: A Case Study of the Oil Spills in Bodo" (2015) 2 (4) The Extractive Industries and Society 615, pp. 615-624.

26 HLPE, "Food Security and Climate Change: A Report by the High-Level Panel of Experts on Food Security and Nutrition of the Committee on World Food Security" (2012) <http://www.fao.org/fileadmin/user_upload/hlpe/hlpe_documents/ HLPE_Reports/HLPE-Report-3-Food_security_and_climate_changeJune_2012.pdf $>$ accessed 3 March 2015. 
reason, the coping capacity of the poor will have to be strengthened, since poor nations and the poor in all nations will be the first and the most to suffer adverse consequences of climate change. ${ }^{27}$

However, in relation to this, it is also important to mention that efforts targeted at combating climate change may also undermine the human right to food, as well as other human rights. During the last decade, the human rights impacts associated with carbon projects, especially in developing countries, have raised considerable concern, ${ }^{28}$ particularly in relation to the rights of indigenous groups. ${ }^{29}$ These concerns have given rise to the climate justice approach that tries to safeguard the rights of the most vulnerable people and sharing the burdens and benefits of climate change and its impacts fairly. ${ }^{30}$ This approach tries to prevent undesirable consequences for present generation of right-holders of actions to protect the environment and the rights to future generations, such as climate change mitigation projects.

In relation to that, in a context of Anthropocene's deepening socioecological crisis, ${ }^{31}$ a crucial question regarding the implementation of the right to food should be posed, that is: is the human rights-based approach to food security sufficient to address the impact of

27 Ibid.

28 Damilola Olawuyi, The Human Rights-Based Approach to Carbon Finance (Cambridge University Press, 2016); Damilola Olawuyi, "Climate Justice and Corporate Responsibility: Taking Human Rights Seriously in Climate Actions and Projects" (2016) 34(1) Journal of Energy \& Natural Resources Law 27, 27-44. UNEP, Climate Change and Human Rights (2015) <https:// www.unenvironment.org/NewsCentre/default.aspx? DocumentID $=26856 \&$ ArticleID $=35630>$ accessed 6 April 2018 .

29 Kristen Taylor, "Improving Substantive and Procedural Protections for Indigenous Rights in REDD + Projects: Possible Lessons from Brazil" (2015) 5(1) Journal of Sustainable Development Law and Policy 32, pp. 32-54; Cams Soria Dall'Orso, “Increased Relevance and Influence of Free Prior Informed Consent, REDD, and Green Economy Principles on Sustainable Commons Management in Peru" (2015) 5 (1) Journal of Sustainable Development Law and Policy 4.

30 Mary Robinson Foundation, "Climate Justice: Principles of Climate Justice" <https://www.mrfcj.org/principles-of-climate-justice/> accessed 19 June 2018.

31 Louis J. Kotzé and Duncan French, "The Anthropocentric Ontology of International Environmental Law and the Sustainable Development Goals: Towards an Ecocentric Rule of Law in the Anthropocene" (2018) 7(1) Global Journal of Comparative Law 5, pp. 5-36. 
environmental degradation on the right to food and confront the tradeoffs between present and future needs? To answer this question, it is useful to analyse the conceptual underpinnings of the HRBA, paying attention to the literature revolving around the linkages between human rights and the environment. The next section delves into this body of literature, paying special attention to how the relationship between environmental degradation and the right to food has been considered and depicted by human rights organizations and scholars. This review may shed light on the appropriateness of the HRBA to tackle the environmental degradation that infringes upon the right to food in the context of the 2030 Development Agenda.

\section{THE RIGHT TO FOOD AND THE LITERATURE ON THE RELATIONSHIP BETWEEN HUMAN RIGHTS AND THE ENVIRONMENT}

The relationship between the environment and human rights was first discussed in the United Nations Conference on the Human Environment in 1972. This was the conference that put environmental issues on the global agenda for the first time. In fact, Principle 1 of the Declaration of the 1972 United Nations Conference on the Human Environment, generally referred as the Stockholm Conference, stresses that "Man has the fundamental right to freedom, equality and adequate conditions of life, in an environment of a quality that permits a life of dignity and well-being". ${ }^{32}$ Thus, the environment was seen as the foundation of a life of dignity, the value that underpins human rights. Therefore, since the Stockholm conference, a substantial amount of legal research has explored the nature of the relationship between human rights and the environment, addressing also the linkages with the right to food. To appraise this literature, subsection 4.1 pays attention to how this issue has been depicted by the work of UN bodies, while subsection 4.2 explores the main approaches to these issues in related literature.

32 United Nations Conference on the Human Environment (UNCHE), "Declaration of the United Nations Conference on the Human Environment", 16 June 1972, <http://www. unep. org/Documents. Multilingual/Default. Asp > accessed 3 March 2015. 


\subsection{The Environment in the UN Human Rights Discourse}

Although the Stockholm conference already made the connection between human rights and the environment in the early seventies, UN human rights bodies did not address this issue until two decades later. Since then, the various UN human rights bodies have tried to connect human rights and the environment, particularly the Human Rights Commission (CHR) and its successor the Human Rights Council (HRC), the Office of the High Commissioner for Human Rights (OHCHR) and some of the special procedures established by the HRC.

An important milestone stating the interconnection of human rights and the environment was the Ksentini Report, presented in 1994, which stressed the impact of environmental degradation on vulnerable groups and analysed the effects of the environment on the enjoyment of various human rights, including the right to food. ${ }^{33}$ More than 10 years later, after its establishment in 2006, the new HRC also dealt with this matter, issuing various resolutions. ${ }^{34}$ In those resolutions, the HRC repeatedly stated that environmental degradation and global climate change played an important role in massive violations of the right to adequate food, particularly in developing countries. ${ }^{35}$ Furthermore, in order to study this issue in depth, the HRC called for an analytical study of the relationship between human rights and the environment in $2011,{ }^{36}$ an assignment carried out in the same year. The ensuing study prepared by OHCHR recognized the link between environmental degradation, including pollution of air, water and land, and the realization of

331 OHCHR, "Review of Further Developments in Fields with which the SubCommission Has Been Concerned, Human Rights and the Environment: Final Report" by Mrs. Fatma Zohra Ksentini, Special Rapporteur (1994) E/CN.4/ Sub.2/1994/9, 44.

34 Including UNHRC Resolutions 7/23 of 28 March 2008 and 10/4 of 25 March 2009 on Human Rights and Climate Change, and Resolutions 9/1 of 24 September 2008 and 12/18 of 2 October 2009 on the Adverse Effects of the Movement and Dumping of Toxic and Dangerous Products and Wastes on the Enjoyment of Human Rights.

35 Also stated in UNHRC resolutions 7/14 of 7 March 2008 on the Right to Food, 10/12 of 26 March 2009 on the Right to Food, 13/4 of 26 March 2010 on the Right to Food and 16/27 of 25 March 2011 on the Right to Food .

36 UNHRC, Human Rights and the Environment, A/HRC/RES/16/11, 12 April 2011, <http://www2.ohchr.org/english/bodies/hrcouncil/docs/16session/ A.HRC.RES.16.11_en.pdf $>$ accessed 2 March 2015. 
particular rights, such as the rights to life, food and health. The study concluded that "human rights and the environment are explicitly and implicitly interrelated". ${ }^{37}$

Additionally, a recent example of collaboration between the OHCHR and the United Nations Environment Program (UNEP) tried to bring together a rights-based and an environmentally-focused approach to the study of the same issue. Therefore, in 2012, both UN bodies presented a Joint Report on Human Rights and the Environment in the third United Nations Conference on Sustainable Development, tagged Rio +20 . This report was aimed at contributing to the conference "through an analysis of the interrelationship between human rights and the environment as they both form integral and indivisible parts of sustainable development". ${ }^{38}$ According to the report, this linkage is central to the efforts to achieve a green economy, as "without integrating human rights and environmental protection, sustainable development and the green economy will not succeed". ${ }^{39}$

Also, it is necessary to mention the contribution of the HRC Special Procedures to the clarification of this relationship. First, the former Special Rapporteur on the right to food Olivier De Schutter has dedicated considerable time to these issues, particularly examining the relationship between agribusiness, environmental degradation and human rights. More specifically, his later work concentrated on how food systems might be reformed to ensure a fuller realization of the right to adequate food, stressing that agricultural productivity depends on the services rendered by ecosystems ${ }^{40}$ and focusing on specific issues such as the impact of the destruction of the world's fisheries on the right to food. ${ }^{41}$ Second, the Special Rapporteur on the illicit movement

37 OHCHR, "Analytical Study on the Relationship between Human Rights and the Environment", A/HRC/19/34, para 7, <http://ieenvironment.org/wpcontent/uploads/2013/05/Analytical-study-OHCHR-PDF.pdf $>$ accessed 4 March 2015.

38 OHCHR-UNEP $2012 \operatorname{Report}(n$ 4).

39 Ibid 6.

40 UNHRC, "Report of the Special Rapporteur on the Right to Food", Olivier De Schutter (2009) A/HRC/13/33/Add.2, para 21<http://www2.ohchr.org/ english/bodies/hrcouncil/docs/13session/A-HRC-13-33-Add2.pdf $>$ accessed 19 June 2018.

41 General Assembly, "Interim Report of the Special Rapporteur on the Right to Food" (2012) A/67/268 <http://daccess-dds-ny.un.org/doc/UNDOC/GEN/ N12/456/40/PDF/N1245640.pdf?OpenElement> accessed 2 March 2015. 
and dumping of toxic and dangerous products and wastes has also studied the implication of environmental degradation on human rights. Interestingly, the Special Rapporteur called on the HRC to give toxic waste management more serious attention even as he complained about the lack of attention of the mandate, as he was often confronted with arguments suggesting that those issues were more appropriately discussed in environmental forums than on the Council. ${ }^{42}$ Third, the first Special Rapporteur on human rights and the environment ${ }^{43}$ published a report in March 2014 on human rights obligations relating to the enjoyment of a safe, clean, healthy, and sustainable environment. There, he noted that many issues related to the obligation that human rights law imposes regarding environmental protection need greater study and clarification. ${ }^{44}$

\section{2 "Human Rights and the Environment" in the International Legal Literature}

Parallel to the work developed within the UN, international legal scholars had also explored the relationship and linkages between human rights and the environment from different perspectives. ${ }^{45}$ The first approach considers human rights as procedural tools to address environmental issues. From Stockholm until the mid-nineties, a big part of the environmental community pressed for the recognition of procedural rights, specifically, access to environmental information, public participation in decision making, and access to justice and remedies in the event of environmental harm, which were seen as underpinning an effective environmental protection. ${ }^{46}$ As a result,

42 UNHRC, Report of the Special Rapporteur on the Adverse Effects of the Illicit Movement and Dumping of Toxic and Dangerous Products and Wastes on the Enjoyment of Human Rights (2008) A/HRC/9/22, para 34.

43 UNHRC Resolution 19/10 of 19 April 2012 on Human Rights and Environment created the mandate on the issue of human rights obligations relating to the enjoyment of a safe, clean, healthy and suitable environment.

44 UNHRC, Report of the Independent Expert on the issue of human rights obligations relating to the enjoyment of a safe, clean, healthy and sustainable environment, John H. Knox (2012) A/HRC/22/43 < http://ieenvironment.org/ annual-reports/> accessed the 2 March 2015.

45 UNHCR, OHCHR 2011 Report para 2 http://www2.ohchr.org/english/ ohchrreport2011/web_version/ ohchr_report2011_web/index.html> accessed 19 June 2018.

46 United Nations Office of the High Commissioner for Human Rights and United Nations Environment Programme, Human Rights and the Environment. Rio+20: 
procedural rights were successfully mainstreamed into environmental protection as, since 1992, all global and regional environmental treaties contain at least some reference to public information, access or remedies. ${ }^{47}$

The second approach has focused on the formulation of a substantial right to a healthy environment. This right was only universally acknowledged in a non-binding resolution of the UN General Assembly (45/94), which stated that "all individuals are entitled to live in an environment adequate for their health and well-being". Nevertheless, since then, many have doubted the benefit of formulating a new human right to a healthy environment. Specifically, some have argued that it is problematic to establish a qualitative level of environment guaranteed, ${ }^{48}$ while others have pointed at the impossibility of developing justiciable standards to enforce the right because of the intrinsic variability of environmental conditions. ${ }^{49}$

The third and last approach emphasizes the environmental dimensions of certain protected rights which consider the environment as a precondition to the enjoyment of human rights. This approach underscores that environmental degradation, including pollution of air, water and land, can affect the realization of particular rights, such as the rights to life, food and health. ${ }^{50}$ In fact, regional human rights courts have recognized the protection of the environment when interfered with the protection of other human rights, such as the protection of private and family life. ${ }^{51}$ As a result, in the decades since Stockholm, a set of environmental rights understood as rights related

Joint Report OHCHR and UNEP (2012) $11<$ http://ieenvironment.org/ wpcontent/uploads/2013/05/JointReportOHCHRandUNEPonHumanRights andtheEnvironment.pdf $>$ accessed 3 March 2015.

47 Ibid.

48 Iveta Hodkova, "Is There a Right to a Healthy Environment in the International Legal Order" (1991) 7 Connecticut Journal of International Law 65; James W. Nickel, "The Human Right to a Safe Environment: Philosophical Perspectives on Its Scope and Justification" (1993) 18 Yale Journal of International 281.

49 Gunther Handl, "Human Rights and Protection of the Environment: A Mildly "Revisionist" View, in Antonio Augusto Cancado Trindade (ed.), Human Rights, Sustainable Development and the Environmental Protection (San Jose de Costa Rica and Brasilia: Instituto Interamericano de Derechos Humanos, 1992), pp. 121-22.

50 OHCHR 2011 Report, (n 45) para 7.

51 See landmark case of the European Court of Human Rights, López Ostra v. Spain (1994), App no 16798/90. 
to environmental protection were added to the body of human rights law.

Therefore, these first attempts to integrate human rights and the environment by international legal scholars made some important contributions to include environmental protection into an HRBA, such as procedural rights, the right to a healthy environment and the recognition of the environmental dimensions of recognized rights. Nevertheless, the common vision of the environment as a mere source of well-being and resources for human beings shared by the abovementioned approaches has led to considerable criticism. These approaches, mainly based on the recognition of a set of environmental rights, were characterized from eco-centred positions as individualistic and anthropocentric. ${ }^{52}$ For instance, in his influential theory of intergenerational equity, E. Brown Weiss notes that the concern over environmental externalities focuses mainly on the costs that we and our contemporaries must bear, for example when we pollute the air. ${ }^{53}$ This view is shared by human rights scholars and institutions who only take the environment into account as long as the aforementioned externalities impact the enjoyment of human rights of living human beings. In relation to that, Redgwell criticizes the formulation of environmental rights, arguing that its existence underpins the idea that the environment and its resources exist only for the human wellbeing and have no intrinsic worth. In similar vein, Bosselman considers that this instrumental view of the environment is problematic as anthropocentric approaches to environmental protection perpetuate "the values and attitudes that are at the root of environmental degradation and deprive the environment of direct and comprehensive protection". ${ }^{54}$ In a similar vein, Birnie and Boyle criticized the hierarchy according to which humanity is given a position of superiority and importance above and separate from other members of the natural

52 Catherine Redgwell, "Life, the Universe and Everything: A Critique of Anthropocentric Rights" in Alan E. Boyle and Michael R. Anderson, Human Rights Approaches to Environmental Protection (Clarendon Press, 1996) pp. 71-88.

53 Edith Brown Weiss, In Fairness to Future Generations: International Law, Common Patrimony, and Intergenerational Equity (United Nations University, 1989) p. 19.

54 Klaus Bosselmann, The Principle of Sustainability: Transforming Law and Governance (Ashgate Publishing, Ltd, 2013). 
community. ${ }^{55}$ This instrumental view of the environment has been characterized as problematic, as anthropocentric approaches to environmental protection perpetuate "the values and attitudes that are at the root of environmental degradation and deprive the environment of direct and comprehensive protection". ${ }^{56}$

Using similar arguments, the capacity of the HRBA to tackle the current environmental challenges may be questioned. More concretely, four relevant gaps may be pinpointed: First, from a human rights perspective, the environment is seen as a mere source of well-being, and it is not granted with any value beyond the satisfaction of human needs. Second, the HRBA has not been able conceptually to incorporate the needs of future generations, as it considers that only present generations have rights. Consequently, the HRBA only takes into account the rights of generations currently alive. Third, despite recent developments, UN human rights institutions have failed so far to give serious attention to the environment and to frame environmental issues with clear human rights implications as human rights problems, as it was pinpointed by the Special Rapporteur on the illicit movement and dumping of toxic of dangerous products. And, fourth, as Birnie and Boyle stressed, this approach has not provided any tangible tools to consider the competing interests of states, ${ }^{57}$ as it is centred on highlighting the obligations of states towards their own populations and not towards the global community as a whole.

\section{SUSTAINABLE DEVELOPMENT AND THE RIGHT TO FOOD IN THE 2030 AGENDA}

\subsection{Sustainable Development: Filling the Gaps of the HRBA}

In the case of food security, the impact of environmental degradation on the right to food calls for a reflection on its conceptual underpinnings and its consideration of the environment. As the literature examined shows, the HRBA to food security may not be sufficient to address

55 Patricia W. Birnie and Alan E. Boyle, International Law and the Environment (Oxford University Press, 1992), p. 193.

56 Bosselmann (n 54).

57 Patricia W. Birnie and Alan E.Boyle, International Law and the Environment (Oxford: Clarendon Press, Pbk. repr. (with corr.) 1994), p. 194. 
current environmental challenges, including climate change, and its impacts on the right to food. Therefore, as Birnie and Boyle argued, a new framework is needed to complement the HRBA. Some have found such a framework in the concept of sustainable development. ${ }^{58}$ Consequently, sustainable development may work as a factor of convergence, as it provides a framework that includes both human rights and environmental protection and that considers the needs of future generations. According to the definition in the Brundtland report, development is sustainable when it "meets the needs of the present without compromising the ability of future generations to meet their own needs". ${ }^{59}$ Since then, it has recurrently highlighted in successive summits that development must be sustainable. In the Rio Declaration, states affirmed that "environmental protection shall constitute an integral part of the development process and cannot be considered in isolation from it" (principle 4). More than two decades after, sustainable development is still the framework that generates more consensus among different actors at the global level. In fact, the SDGs that succinctly express the global agenda priorities for the next 15 years are framed under this concept.

Human rights and environmental protection are two of the three pillars of the concept of sustainable development. Initially conceived as a concept integrating two "interdependent and mutually reinforcing pillars", economic development and environmental protection, after the Johannesburg Declaration, social development was added as a new pillar. ${ }^{60}$ This pillar is frequently equated with human rights law, ${ }^{61}$ particularly since the resolution 2003/71 of the CHR, which states that "peace, security, stability and respect for human rights and fundamental freedoms, including the right to development, as well as respect for cultural diversity are essential for achieving sustainable

58 In fact, the third approach identified by the OHCHR and UNEP framed the relationships between the environment and human rights within the concept of sustainable development.

59 Gro H. Brundtland, Report of the World Commission on Environment and Development: Our Common Future (United Nations, 1987) < http://www.undocuments.net/our-common-future.pdf $>$ accessed 15 March 2015.

60 World Summit on Sustainable Development, Johannesburg Declaration on Sustainable Development (2002), art. 5, A/CONF.199/20, para 5.

61 Dominic McGoldrick, "Sustainable Development and Human Rights: An Integrated Conception" (1996) 45(4) International and Comparative Law Quarterly 796, pp. 796-818. 
development and ensuring that sustainable development benefits all". ${ }^{62}$

The linkages between these two pillars have also been translated to the field of international law. Since the Rio Summit, a big part of the international legal community has stressed the legal nature of sustainable development, as it has penetrated the sources of international law and has given rise to valid rules of law. ${ }^{63}$ Moreover, the concept of sustainable development has been creatively used by a group of international legal scholars who consider sustainable development not only as a norm but as a new branch of international law: sustainable development law. This new branch of law is defined as "the body of legal principles, treaties and legislation, and legal instruments, which govern the area of intersection between social, economic and environmental law for sustainable development". ${ }^{64}$ The added value of this body of law situated at the intersection between these three spheres is the fact that can provide balance, strengthening the frequently neglected social and environmental aspects of globalization. ${ }^{65}$ Accordingly, the temple-like structure is here replicated: the central pillar is international environmental law; the second pillar is international human rights law, ${ }^{66}$ and the third pillar is international economic law. This view is consistent with Rodrigo's proposal which considers sustainable development as a framework in international law and provides an integrated approach for the creation and interpretation of public policies, some international law principles and hermeneutical resources to solve controversies. ${ }^{67}$ Thus, this approach offers a set of legal tools such as international principles or hermeneutical resources to solve controversies for further integrating human rights law and environmental law.

62 Commission on Human Rights, "Human rights and the environment as part of sustainable development", E/CN.4/RES/2003/71 < http://www.refworld.org/ docid/43f3134dc.html> accessed 3 March 2015.

63 Virginie Barral, "Sustainable Development in International Law: Nature and Operation of an Evolutive Legal Norm" (2012) 23(2) European Journal of International Law 377, pp. 377-400.

64 Marie-Claire Cordonier Segger and Ashfaq Khalfan, Sustainable Development Law: Principles, Practices, and Prospects (OUP Catalogue, 2004).

65 Marie-Claire Cordonier Segger, "Significant Developments in Sustainable Development Law and Governance: A Proposal" (2004) 28(1) Natural Resources Forum 61, pp. 61-74.

66 Ibid.

67 Á. J. Rodrigo Hernández, "El Concepto de Desarrollo Sostenible en el Derecho Internacional" (2006) 8 Agenda ONU: Anuario de la Asociación para las Naciones Unidas en España 159, pp. 159-214. 


\subsection{The Principles of Sustainable Development Law as Tools for Greater Integration with the Right to Food}

After stating the need for a greater integration, the question now is which specific legal tools should be used to further integrate sustainable development and the right to food. From the sustainable development perspective, the implementation of the right to food is part of its agenda as it is a crucial aspect of social development. Thus, the legal tools provided by international sustainable development law may be used to integrate sustainable development and the right to food in the 2030 development framework. In that regard, international law can play an important role in the implementation of sustainable development as it offers, on the one hand, a set of tools to consolidate an integrated approach and, on the other hand, a regulatory framework for cooperation of all relevant actors. ${ }^{68}$ In particular, it offers a set of principles that may play different roles in the implementation: guide the adoption of policies and legal norms, create rights and obligation for states and, help implement and interpret existing norms.

More concretely, a clear set of legal tools is provided by the Principles of International Law for Sustainable Development, generally known as the New Delhi Declaration, elaborated in 2002 by the International Law Association (ILA) Committee on the Legal Aspects of Sustainable Development. This instrument identified seven principles that seek to integrate, in a balanced way, economic, social and environmental interests. In that regard, the ILA Principles are consistent with the 2002 Johannesburg Plan of Implementation, as they help to focus decision-makers' attention on expected outcomes for all those elements, as well as on governance structures and processes conducive to their effective implementation. ${ }^{69}$ These seven principles are: the duty of states to ensure sustainable use of natural resources; the principle of equity and the eradication of poverty; the principle of common but differentiated responsibilities; the principle of the precautionary approach to human health, natural resources and ecosystems; the

68 Philippe Sands, "Environmental Protection in the Twentieth Century: Sustainable Development and International Law", in Norman J. Vig and Regina S. Axelrod (eds) The Global Environment: Institutions, Law And Policy (Earthscan, 1999).

69 Maja Goepel, "Formulating Future Just Policies: Applying the Delhi Sustainable Development Law Principles" (2010) 2(6) Sustainability, p. 1694. 
principle of public participation and access to information and justice; the principle of good governance; and the principle of integration and interrelationship, which relates particularly to human rights and social, economic and environmental objectives.

Some principles are common with the HRBA, such as the principle of public participation and access to information and justice, and the principle of good governance. Others, however, come from other areas of international law. These norms have different legal values, as several are not yet recognized as binding rules of customary international law. However, they are increasingly made operational in binding international treaties, forming part of international law and policy in the field of sustainable development, providing normative context for best policies and laws in the field, as well as in Local Agenda 21 initiatives and national sustainable development strategies. ${ }^{70}$ Among these principles, three of them seem particularly useful to fill some of the gaps of the HRBA. These are the principle of sustainable use of natural resources, the principle of equity and eradication of poverty, and the principle of common but differentiated responsibilities and the right to food.

\subsubsection{The Principle of Sustainable Use of Natural Resources and the Right to Food}

The first principle refers to the duty of states to ensure sustainable use of natural resources. The origin of this principle is found in the international norms adopted for the conservation of natural resources, such as fisheries, for international rivers regulation, and, more recently, for biodiversity conservation. According to point 1(2) of the New Delhi Declaration, "states are under a duty to manage natural resources, including resources within their own territory or jurisdiction, in a rational, sustainable and safe way to contribute to the development of their peoples, with respect to the rights of indigenous peoples, and to the conservation and sustainable use of natural resources and the protection of the environment, including ecosystems". ${ }^{71}$ Thus, this

70 Ibid.

71 ILA, "ILA New Delhi Declaration of Principles of International Law Relating to Sustainable Development" (2002) 2(2) International Environmental Agreements: Politics, Law, and Economics 211, pp. 211-216, < http://cisdl.org/ tribunals/pdf/NewDelhiDeclaration.pdf $>$ accessed 3 March 2015. 
principle establishes a limit of the principle of permanent sovereignty over natural resources, as it is recognized in the resolution of the General Assembly 1803 (XVII) of the 14 December 1962. Those limits are a consequence of the obligation of causing no harm to the environment, which is part of general international law, as it was admitted by the International Court of Justice (ICJ). In accordance with the International Law Commission (ILC), this principle is part of customary law. ${ }^{72}$

However, the generality of the content of this principle calls for a greater specification, in terms of specific resources and contexts. In the context of food security, this principle was considered within Guideline $8 \mathrm{E}$ of the RtFG, which affirms that states should "promote the sustainable management of fisheries and forestry". Regarding water resources, Guideline 8.11 stresses that states should improve access to water resources and promote its sustainable use and allocation and that "the equitable distribution of water must satisfy basic human needs and reconcile the preservation of ecosystems with domestic, industrial and agricultural needs". ${ }^{73}$ Also, the FAO has recently published a report exploring the relationship between national resources governance and the right to adequate food, focusing on the incorporation of a human rights-based approach to natural resources. ${ }^{74}$

Nevertheless, the human rights based-approach does not provide any specific tools to hold both state and private actors to account for the use of natural resources. As previously stated, the impact of business activity on natural resources, especially on water resources, may seriously impinge on the enjoyment of the right to food. However, the human rights-based approach focuses on stressing the obligations of states to control private actors, but it does not provide any tools to hold them to account for the use of natural resources. Therefore, the implementation of this principle can complement the human rightsbased approach as it calls for holding those actors to account for the economic losses that are experienced by using renewable and nonrenewable resources in the environment, as the green accounting

72 ILA, Yearbook of the International Law Commission (1994) Vol II, Part II, para 10.

73 RtFG (n 13).

74 Luisa Cruz and Margret Vidar, "Natural Resources Governance and the Right to Adequate Food" (FAO Legal Office, 2004) < http://www.fao.org/3/ai3893e.pdf) > accessed 3 March 2015. 
proposal suggests. ${ }^{75}$ As Futrell points out, the transition to sustainability will not take place without a fundamental change in economics, since "prices fail to reflect the full costs to the environment and environmental goods and services are undervalued or are free for the taking". ${ }^{76}$ As the OHCHR-UNEP 2012 Report argued, a green accounting system which provides information on the degradation of ecosystems and their services will offer "the opportunity to help meet goals of reducing poverty and sustainable development and allow for the monitoring of environmental degradation that may affect human rights". ${ }^{77}$ Therefore, legal frameworks that reward private actors for positive environmental externalities, ${ }^{78}$ such as payments for ecosystem services, and in turn tax them for negative environmental externalities, such as use of natural resources, should be urgently developed and integrated into global and national policies. Moreover, specific tools aimed at increasing accountability in the use and management of natural resources can be also useful, both at the national and at the global level.

First, one interesting tool to reward farmers and food producers are payments for ecosystem services (PES), ${ }^{79}$ which have become

75 OHCHR-UNEP 2012 (n 4).

76 J. William Futrell, "The Transition to Sustainable Development Law" (2003) 21(1) Pace Envtl L Rev.179. In regard to agriculture, market prices continue to favour large-scale industrial agriculture to the extent that markets fail to internalize its environmental costs, such as pollution and depletion of water resources, and fail to reward the positive environmental externalities associated with small-scale sustainable agriculture, such as soil and water conservation, stewardship of agrobiodiversity, and carbon sequestration. Carmen G. Gonzalez, "International Economic Law and the Right to Food" in Nadia Lambek, Priscilla Claeys, Adrienna Wong, Lea Brilmayer, Rethinking Food Systems (Springer Netherlands, 2014), pp. 165-193.

77 OHCHR and UNEP report, 2012 (n 4).

78 As the Special Rapporteur Olivier De Schutter suggested, the role played by the services rendered by ecosystems in agricultural productivity should be considered in the reform of food systems. The UNTAD in a report about trade and environment published in 2013, called for a move from a linear to a holistic approach in agricultural management, a change to consider that a farmer is not only a producer of agricultural goods, but is also a manager of an agroecological system that provides a number of public goods and services, water, soil, landscape, energy, biodiversity and conservation. UNCTAD Trade and Environment Review 2013, "Wake Up before It Is Too Late" < http://unctad.org/ en/PublicationsLibrary/ditcted2012d3_en.pdf> accessed 19 June 2018.

79 Payments for Environmental Services ( $\overline{\mathrm{PES}}$ ) are based on incentives offered to farmers for managing their land to provide environmental services, such as 
increasingly popular to manage ecosystems using economic incentives. ${ }^{80}$ In agriculture, PES can provide positive incentives to natural resources conservation, such as rewarding hydrological, environmental services. For instance, a PES scheme has been put in practice in the Cañete River watershed in Peru to provide incentives for the sustainable use of the river's water. In this basin, the highest demand for water resources for agriculture and drinking water is concentrated in the lower watershed. Thus, the upper watershed region provides two main ecosystem services: water yield, i.e., a sufficient amount of available runoff water for downstream users, and year-round availability of water. ${ }^{81}$ Hence, the PES scheme rewards communities in the upper basin for the conservation services that they provide. Furthermore, this scheme has also been pinpointed as a tool to reduce the wealth inequality gap, as upstream communities are poorer than communities downstream. ${ }^{82}$ This case was a pilot case, to be replicated in other similar ecosystems in Peru. Nevertheless, its evaluation identified the difficulties attached to the lack of recognition of PES schemes in the legislation, as "financial, institutional and legal bottlenecks slow down the advancement of all these initiatives towards effective operationalization". ${ }^{83}$ According to Quintero, researchers are working with the Peruvian government on the creation of a new law for promoting reward schemes in Peru that will incorporate the lessons learnt from the Cañete Basin scheme.

biodiversity habitats, watershed protection, and carbon sequestration. FAO, "Remuneration of Positive Externalities (RPE) Payments for Environmental Services (PES) in the Agricultural and Food Sectors" (2013) <http:// www.fao.org/fsnforum/sites/default/files/files/88_PES/NRD_ PESflyer_v2.pdf $>$ accessed 20 March 2015.

80 Joshua Farley, Robert Costanza, "Payments for Ecosystem Services: From Local to Global" (2010) 69 (11) Ecological Economics 2060-2068 <https:// www.uvm.edu/giee/pubpdfs/Farley_2010a_Ecological_Economics.pdf > accessed 20 March 2015.

81 Marcela Quintero, Abby Waldorf, "Can Rewards for Ecosystem Services Reduce the Wealth Inequality Gap?", Thrive, Agriculture and Ecosystems Blog, 27 August 2013 < http://wle.cgiar.org/blogs/2013/08/27/can-rewards-forecosystem-services-close-the-wealth-inequality-gap/> accessed 20 March 2015.

82 Ibid.

83 FAO, "Rewarding Water-Related Ecosystem Services in the Canete Basin, Peru", Case studies on Remuneration of Positive Externalities (RPE)/Payments for Environmental Services (PES), Prepared for the Multi-stakeholder Dialogue, 12-13 September 2013, FAO < http://www.fao.org/fileadmin/user_upload/ pes-project/docs/FAO_RPE-PES_CIAT_Peru.pdf > accessed 20 March 2015. 
Second, there is also an interesting set of tools aimed at regulating the negative externalities derived from the use of natural resources. On the one hand, there is a wide array of control instruments at the national level that states can use, such as regulations, controls and bans on certain types of resource use or agricultural practices. ${ }^{84}$ For instance, one classical example is quotas, for example for the amount of water that can be drawn from a river or other source, the size of trees that can be cut or the size and composition of fish catches. ${ }^{85}$ Nevertheless, quotas and other control mechanisms are difficult and expensive to enforce by forestry and fishing, mainly because of the geographically dispersed nature of farming. In relation to that, a 2012 report of the OECD, Green Growth and Developing Countries, pointed at some specific resources that those countries can use to improve the efficiency of the way natural resources are being used. ${ }^{86}$ Some of these instruments are taxes or royalties on natural resource extraction, user charges for services such as water supply and waste management to recover costs and environmentally-related taxes such as pollution charges. These instruments are particularly useful to developing countries because they can contribute to revenue increases which can be used for environmental and poverty reduction. ${ }^{87}$ For instance, in Cameroon, forest fiscal reform provided revenue to back the implementation of actions to promote sustainable forest management. However, the need to ensure that a share of the revenues actually reaches local communities has been highlighted. ${ }^{88}$

Third, tools aimed at increasing accountability in the use and management of natural resources should be developed as well. A good recent example is FAO Committee on Fisheries' (COFI) initiative to

84 FAO, "Guidelines for the Integration of Sustainable Agriculture and Rural Development into Agricultural Policies" (1997), 4 FAO Agricultural Policy and Economic Development Series <http://www.fao.org/docrep/w7541e/ w7541e08.htm\#6.5> accessed 20 March 2015.

85 Ibid.

86 United Nations Economic and Social Commission for Asia and the Pacific (ESCAP), "Green Growth at a Glance: The Way Forward for Asia and the Pacific", ESCAP, 2006, <https://sustainabledevelopment.un.org/content/documents/ 784GGBrochure.pdf $>$ accessed 20 March 2015.

87 Organization for Economic Co-operation and Development (OECD), "Green Growth and Developing Countries: A Summary for Policy Makers" (OECD, 2012) < http://www.oecd.org/dac/50526354.pdf> accessed 20 March 2015.

88 Ibid. 
establish a Global Record of Fishing Vessels. The Global Record is a voluntary and collaborative global initiative that intends to make information available on vessel identification and other relevant data. ${ }^{89}$ This instrument will help to eliminate illegal, unreported and unregulated fishing through increasing transparency and traceability of vessels and their activities as well as fish products. ${ }^{90}$ Similar initiatives would help to manage natural resources through increasing monitoring and accountability.

\subsubsection{The Principle of Equity and the Eradication of Poverty and the Right to Food}

This principle brings two fundamental elements into the conceptualization of sustainable development: the necessity to consider the needs of all members of present generations and the needs of future generations. Accordingly, therefore, principle 2 of the declaration refers to both intergenerational equity, namely the right of future generations to enjoy a fair level of the common patrimony, and intragenerational equity, the right of all peoples within the current generation of fair access to the current generation's entitlement to the Earth's natural resources. ${ }^{91}$ On the one hand, the principle of intergenerational equity implies that states must preserve the environmental capital they hold in trust for future generations in their developmental choices and ensure that it is transmitted under conditions equivalent to those in which it was received.$^{92}$ In other words, it implies that current generations have an obligation to refrain from depriving future generations of the means to meet their own needs. On the other hand, the principle of intragenerational equity requires equity in the distribution of the outcomes of development within one generation as much internally, within a given state, as internationally, between developed and

89 More information at: <http://www.fao.org/fishery/global-record/en > accessed 20 March 2015.

90 FAO, "Global Record of Fishing Vessels, Refrigerated Transport Vessels and Supply Vessels: The Way Forward", Strategy document, <http://www.fao.org/ cofi/33133-01d7de5488a77180759efacea7c39dbb7.pdf $>$ accessed 20 March 2015.

91 ILA New Delhi Declaration (n 71).

92 Edith Brown Weiss, "Implementing Intergenerational Equity" in Malgosia Fitzmaurice, David M. Ong, Panos Merkouris (eds), Research Handbook on International Environmental Law (Edward Elgar Publishing, 2010), p. 100. 
developing countries. ${ }^{93}$ Thus, the principle of equity and the eradication of poverty imply that a just distribution of resources among members of the present generation is part of sustainable development. This principle would suggest that such distribution should focus on meeting the basic needs of the poor, who have the greatest priority in sustainable development. ${ }^{94}$ Both principles are widely considered as emerging principles of international law, as they do not fulfil the criteria to be considered binding international customary law. ${ }^{95}$

There are opportunities to link this principle with the right to food as it complements the focus on the most vulnerable feature inherent in the human rights-based approach, with a perspective that incorporates the needs of future generations. In that regard, Brown Weiss in his prominent theory of intergenerational equity, affirms that sustainability requires that "we look at the earth and its resources not only as an investment opportunity, but as a trust passed to us by our ancestors for our benefit, but also to be passed on to our descendants for their use". ${ }^{96}$ In Brown Weiss words: "as members of the present generation, we are both trustees, responsible for the robustness and integrity of our planet, and beneficiaries, with the right to use and benefit from it for ourselves". Hence, two relationships are relevant for this intergenerational equity theory: the first is our relationship with our natural system, of which we are a part; the second is our relationship with other generations. In relation to the later, our connection with future generations is based on the idea of continuity, as "all generations are linked by the ongoing relationship with the Earth". Moreover, all generations have an equal place in relation to the natural system; hence there is no basis for preferring past, present or future generations in relation to the system. ${ }^{97}$ This implies some "planetary rights and obligations" held by each generation, such as the obligations of conserving options for future generations, to maintain the quality of the environment and to give equitable access to the legacy of past

93 Duncan French, "International Environmental Law and the Achievement of Intragenerational Equity”, (2001), 31 Environmental Law Reporter, p. 469.

94 Cordonier Segger (n 65).

95 K. Hossain, "Searching for the Contours of International Law in the Field of Sustainable Development" (2002), Report of International Law Association, New Delhi Conference, 6.

96 Brown Weiss (n 91) 20.

97 Ibid. 
generations to the present generation. As far as the enforcement of these rights is concerned, she proposes to give representation to the interests of future generations in decision-making processes, ${ }^{98}$ including the market. ${ }^{99}$

However, the idea that all generations have an equal place in relation to the natural system is extremely controversial, especially when we deal with the trade-offs between the protection of the interests of present and future generations. Coming back to Brown Weiss, she notes that in many instances, the actions needed to meet the basic needs of the poor are consistent with those advancing intergenerational equity. ${ }^{100}$ However, she also recognizes that, sometimes, the action needed to protect the rights of future generations may conflict with the immediate needs of alleviating poverty. In a similar vein, it has been emphasized that environmentalism, if not properly handled, could involve severe restrictions of fundamental freedoms for the sake of protecting the environment. ${ }^{101}$

For instance, climate change mitigation solutions such as reducing the emissions of the agricultural sector in developing countries may negatively affect the food security of those countries. ${ }^{102}$ Thus, a new problem ensues when trying to safeguard the interest of future generations infringes upon the interests and rights of the present ones. A thought-provoking answer to that problem points at the "intergenerational linkage" that unites present and future generations. This linkage highlights that future generations are not only the unborn but also the children that are continuously being brought into the planet. Therefore, the consideration of future generations as part of the present and part of a continuum changes considerably the importance of safeguarding the interest of future generations. As Buchanan points out, it is a very different thing to talk about the interests

98 Ibid 25.

99 Regarding the later, she suggests that relevant market instruments have to be designed to protect the entitlements of future generations and to achieve international equity efficiently. See Richard B. Norgaard, "Sustainability As Intergenerational Equity: The Challenge to Economic Thought and Practice", in Internal Discussion Paper, Asia Regional Series, Report No. IDP 97 (World Bank 1991).

100 Brown Weiss (n 91) 21.

101 Jorge E. Viñuales, "The Rise and Fall of Sustainable Development" (2013) 22(1) Review of European, Comparative \& International Environmental Law 9. 102 HLPE report, (n 26) 75. 
of today's children and grandchildren, than about the interests of people who will be alive ten, twenty, or one hundred generations from now. ${ }^{103}$ Thus, in some cumulative sense, each generation cares about its children, and each generation will, in turn, teach its children to care about their children. ${ }^{104}$ In that way, every generation has to care in some way about the interests of all future generations and, moreover, future generations are not seen any more as an indeterminate mass of people but as living rights-holders.

Nonetheless, it is important to highlight that the necessary processes to ensure reconciliation between the protection of the interests of present and future generations have to give special priority to the basic needs of the people currently alive. Thus, Brown Weiss states that processes to ensure reconciliation should be developed to deal with these trades-off, but his theory implies that covering the basic needs of the poor should not be hindered by environmental protection. In fact, one of the normative principles of intergenerational equity considers that each generation should provide its members with equitable rights of access to the legacy of past generations, such as the access to potable water supplies. In addition, no unreasonable burdens should be put on the present generation to meet indeterminate future needs. ${ }^{105}$

Hence, it seems that the limit that the principle of intergenerational poses to human rights would be to ensure that the processes to achieve them, respect the planetary rights and duties held by each generation, such as the obligations of conserving options for future generations and to maintain the quality of the environment are kept sacrosanct. In the case of the right to food, this would mean, for instance, respecting and promoting agricultural biodiversity, in order to conserve options for future generations and avoid the use of unsustainable agricultural practices, such as polluting pesticides, to maintain the quality of the environment. Thus, as she argues, the possibility of scrutinizing decisions, such as the best ways to feed the world, also from the point of view of their impact on future generations should be explored. ${ }^{106}$

On the other hand, the principle of intragenerational equity raises the issue of income inequality at the global and national levels, which

103 Neil H. Buchanan, "What Kind of Environment Do We Owe Future Generations?" (2011) 15 Lewis \& Clark Law Review 339.

104 Ibid.

105 Brown Weiss (n 91) 23.

106 Ibid 25. 
is considered as well in SDG-10. Indeed, recent work of the former right to food rapporteur, Olivier de Schutter, pointed at economic inequalities and consumerism as obstacles to achieving sustainability. At the global level, the tastes of wealthy consumers compete against the needs of the poor. For instance, the recent food crisis showed that meat consumption habits by some societal sectors of developed and developing countries may contribute to rising global food prices, which impact negatively on the right to food of poor people in the global South and is a long-term vector of global inequality. ${ }^{107}$ At the national level, it has been underlined that economic inequality and environmental degradation are mutually reinforcing, as large income inequalities can lead to runaway resource use by the wealthy, putting major pressures on the environment. ${ }^{108}$ Moreover, high levels of inequality grant certain groups in society a privileged position and the power to veto any significant changes to existing economic incentives. ${ }^{109}$ In reference to the right to food, research has been conducted about the relationship between social protection measures and the right to food at the national level, looking at the positive effect that the adoption of more redistributive policies and greater equality may have on right to food implementation. ${ }^{110}$ At the international level, some actions can be taken to transform recurrent humanitarian support in some areas like the Sahel in long-term support to establish mechanisms that not only alleviate the effects of shocks but also facilitate the adoption of sustainable practice

\subsubsection{The Principle of Common but Differentiated Responsibilities and the Right to Food}

This principle affirms that although all states and other relevant actors

107 Tony Weis, "The Meat of the Global Food Crisis" (2003) 40(1) Journal of Peasant Studies 65.

108 Olivier De Schutter, “The EU's Fifth Project: Transitional Governance in the Service of Sustainable Societies", Michel Serres Institute for Resources and Public Goods, 2014 <http://www.srfood.org/images/stories/pdf/ otherdocuments/Equality2.pdf> accessed 3 March 2015.

109 Olivier De Schutter, "Are Inequalities an Obstacle to Achieving Sustainability?", Michel Serres Institute for Resources and Public Goods, $2015<$ http:// www.srfood.org/en/are-inequalities-an-obstacle-to-achieving-sustainability > accessed 3 March 2015.

110 Shoghag S. Ajemian, "Social Protection and an Enabling Environment for the Right to Adequate Food" (2014) 5 FAO Thematic Study < http://www.fao.org/ 3/a-i3894e.pdf> accessed 4 March 2015. 
have a duty to cooperate in the achievement of global sustainable development, they bear differentiated responsibilities towards environmental problems. The New Delhi Declaration clarifies that all states are under a duty to co-operate in the achievement of global sustainable development and the protection of the environment. ${ }^{111}$ Hence, international organizations, corporations (including transnational corporations), non-governmental organizations and civil society should co-operate in, and contribute to, sustainable development. Nonetheless, developed countries bear a heavier responsibility in working towards sustainable development, as they have contributed more to the degradation of the environment. Similarly, the economic and developmental situation of states must be taken into consideration, including the "special needs and interests of developing countries and of countries with economies in transition, regarding least developed countries and those affected adversely by environmental, social and developmental considerations", ${ }^{112}$ In practical terms, this principle implies differential treatments and differentiated legal commitments in international environmental treaties, as it was the case in the 1992 Framework Convention on Climate Change (UNFCCC). Additionally, this principle also implies the obligation to carry out technology and financial transfers from developed to developing countries. This principle is considered a fundamental principle of international environmental law but lacks the opinion iuris to be considered part of customary law. ${ }^{113}$ In spite of that, it has been characterized as a crucial legitimation criterion, both for the creation and the interpretation of legal norms ${ }^{114}$ and it has been a crucial legal tool to reconcile the positions of developed and developing states in the negotiation of the climate change regime.

Thus, there are opportunities to link this principle with the right to food, as it helps to address the competing needs of states, mostly regarding the issue of increasing technological transfer from developed to developing countries. As stated in the Rio+20 Declaration, states

111 New Delhi Declaration (n 71).

112 Ibid.

113 Susana Borràs Pentinat, "Análisis Jurídico del Principio de Responsabilidades Comunes, Pero Diferenciadas" (2004) 25(49), Seqüência: Estudos Jurídicos e Políticos 153.

114 Yoshiro Matsui, "Some Aspects of the Principle of 'Common but Differentiated Responsibilities"' (2002) 2(2) International Environmental Agreements 151. 
should "improve access to information, technical knowledge and knowhow, including through new information and communications technologies". ${ }^{115}$ In the case of agriculture, FAO mentioned unsustainable technologies as one of the root causes of unsustainable agricultural practices and degradation of the rural environment, as some have had harmful side effects, such as resistance of insects to pesticides, land degradation through wind or water erosion, nutrient depletion or poor irrigation management and the loss of biological diversity. ${ }^{116}$

Accordingly, greater transfers for sustainable agriculture and climate change mitigation may help the transition to more sustainable food systems and contribute to the right to food implementation. Consequently, states should ensure "access to knowledge and appropriate and affordable technologies, including for efficient irrigation, reuse of treated wastewater and water harvesting and storage". ${ }^{117}$ Furthermore, it has been underlined that it is better to focus on this aspect of the principle instead of allowing looser regulations for developing countries, ${ }^{118}$ with the excuse of giving them flexibility to implement environmental agreements. The rationale behind that is that highly variable environmental regulation between countries creates the potential for pollution havens, which could in turn impact negatively on the right to food.

\section{CONCLUSION}

The gaps in the HRBA call for a better integration of the right to food within the framework of sustainable development. The literature examined showed that the HRBA to food security does not seem sufficient to address environmental problems and constraints that infringe directly on right to food implementation, as it does not provide concrete tools to consider intrinsic values, the needs of future

115 UNGA (n 4).

116 FAO, "Dimensions of Need: An Atlas of Food and Agriculture", (1995) < http: //www.fao.org/docrep/U8480E/U8480E00.htm> accessed 20 March 2015.

117 UN, "UN Water and sustainable Development, From Vision to Action", Report of the 2015 UN-Water Zaragoza Conference.

118 For example, the Montreal Protocol on Substances that Deplete the Oxone Layer introduces a binary differentiation between developed and developing countries, but all states must progressively eliminate the production of listed substances, developing states are only given more flexible deadlines. Viñuales, (n 101). 
generations, and the competing interests of states, as Birnie and Boyle argued. Moreover, in this context of declining natural resources and greater environmental degradation, new solutions should be explored to reconcile the needs of developed and developing countries, and of present and future generations.

Therefore, this article argued for further integrating sustainable development and the right to food through a set of principles of sustainable development law. First, the principle of sustainable use of natural resources raises the question of finding ways to hold both state and private actors to account for the environmental degradation and the use of natural resources. This highlights the urgent need to implement new global and national legal frameworks that reward private actors for positive environmental externalities and in turn penalize them for negative environmental externalities. Second, the principle of equity and eradication of poverty incorporates the needs of future generations to the right to food as well as global justice matters. On the one hand, examining the theory of intergenerational equity points at the necessity of scrutinizing food security decisions from the point of view of their impact on future generations. However, it should be clarified that the needs of the future generations should never be put as an excuse for not realizing the right to food of the present generations, as no unreasonable burdens should be put on the present generation to meet indeterminate future needs. And, last but not least, the principle of common but differentiated responsibilities helps to put the focus on the different responsibilities that the states bear towards climate change and environmental degradation, justifying greater technological transfer for climate change mitigation in agriculture from developed to developing countries that may help the right to food implementation in the latter.

These principles of international law may help the implementation of the right to food, contributing to fill some of the gaps of the HRBA and expanding new avenues for research. In particular, research that clarifies the specific impacts on the right to food of environmental degradation, use of natural resources, economic inequalities and global patterns of consumption would shed light on the sustainable dimensions of the right to food. Nevertheless, legal principles should be accompanied by mechanisms that facilitate their implementation. Thus, public goods such as the global record of fishing vessels that can facilitate accountability and internalization of some externalities need to be identified and further developed for each of the principles. 
Accordingly, further research on how these principles may help the different phases of right to food implementation in different contexts and different levels is highly desirable. 